\title{
HUBUNGAN TINGKAT PENDIDIKAN IBU DENGAN PEMILIHAN ALAT KONTRASEPSI KB SUNTIK DI PUSKESMAS GUNUNG SAMARINDA KOTA BALIKPAPAN TAHUN 2017
}

\author{
Ni Nyoman Widya Pradani, Yunia Ulandari \\ Akademi Kebidanan Bakti Indonesia Balikpapan, email : ninyomanwidyapradani@gmail.com
}

\section{INFO ARTIKEL}

RiwayatArtikel:

Diterima: 20-02-2018

Disetujui: 01-04-2018

\section{Kata Kunci:}

Pendidikan

Pemilihan

Alat Kontrasepsi KB

Suntik

Education

Selection

Contraception of

injection contraception.

\section{A. LATAR BELAKANG}

Paradigma baru program Keluarga Berencana Nasional telah di ubah visinya dari mewujudkan Norma Keluarga Kecil Bahagia Sejahtera (NKKBS) menjadi visi untuk mewujudkan "Keluarga berkualitas tahun 2015". Keluarga yang berkualitas adalah keluarga yang sejahtera, sehat, maju, mandiri, memiliki jumlah anak yang ideal, berwawasan kedepan, bertanggung jawab, harmonis, dan bertaqwa kepada Tuhan Yang Maha Esa, Keluarga adalah salah satu diantara kelima matra kependudukan yang sangat mempengaruhi penduduk yang berkualitas. Visi tersebut dijabarkan dalam enam misi, yaitu: 1) memberdayakan masyarakat untuk membangun keluarga kecil berkualitas, 2) menggalang kemitraan dalam peningkatan kesejahteraan, kemandirian dan ketahanan keluarga, 3) meningkatkankualitaspelayanan KB dan kesehatan reproduksi, 4) meningkatkan promosi,

\section{ABSTRAK}

Abstrak : Kontrasepsi suntik adalah alat kontrasepsi yang berupa cairan yang berisikan mogesterone atau hormon estrogen yang di suntikkan ke bokong atau otot panggu mengetahui tingkat pendidikan ibu dengan pemilihan alat kontrasepsi KB suntik di Puskesmas Gunung Samarinda Balikpapan tahun 2017. Jenis penelitian ini menggunakan metode deskriptif analitik dengan rancangan penelitian cross sectional. Teknik pengambilan

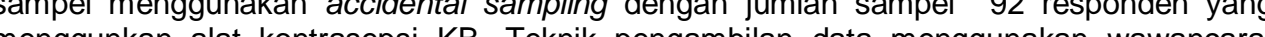
Teknik analisa data menggunakan analisa univariat dengan distribusi frekuensi dan analisa bivariat dengan uji statistic Chi Square $\left(\chi^{2}\right)$ pada taraf signifikan $\alpha 0,05$. Hasil penelitian ini sebanyak 46 orang $(50 \%)$ tingkat pendidikan rendah, sebanyak 75 orang $(81,5 \%)$ memilih 列 Samarinda Balikpapan Tahun 2017. Saran bagi Puskesmas Gunung Samarinda diharapkan erlebih dahulu dalam menetapkan pilihan alat kontrasepsi yang tepat dan sesuai dengan (intinya. Dan bagi responden agar mampu meningkatkan informasi dan wawasan sebagainya sehingga ibu mengetahui apa saja alat kontrasepsi.

Abstract : Injection contraception is a fluid containing contraceptive device containing progesterone hormone or estrogen hormone injection into the buttocks or pelvic muscles in with the selection of contraceptive contraception injection in Gunung Samarinda Public (2017. This research use descriptive analytic method ple number 92 respondents using contraception tool contraceptive. The technique of distribution and using interview. The data analysis using univariat analiysis with frequency level $\alpha$. The results of this study were 46 people (50\%) low level of education, as many 75 people (81,5\%) choose injection contraception, and there was a significant correlation between the levevl of education of the mother with the choice of contraceptive tool for on the results of the above research can be concluded level of maternal education with selection of contraception contraceptive injection at Gunung Samarinda public health center guidance programs, and counseling where WUS are given counseling first in determining the appropriate choice of contraception and in accordance with his situation.

perlindungan, dan upaya mewujudkan hak-hak reproduksi, 5) meningkatkan upaya pemberdayaan perempuan untuk mewujudkan kesetaraan dan keadilan gender melalui program Keluarga Berencana dan 6) mempersiapkan Sumber daya Manusia berkualitas sejak pembuahan dalam kandungan sampai dengan lanjut usia (Saifuddin, 2010).

Banyak perempuan mengalami kesulitan di dalam menentukan pilihan jenis kontrasepsi. Hal ini tidak hanya karena terbatasnya metode yang tersedia, Tetapi juga oleh ketidaktahuan mereka tentang persyaratan dan keamanan metode kontrasepsi tersebut. Berbagai faktor harus dipertimbangakan, termasuk status kesehatan, efeksamping potensial, konsekuensi kegagalan atau kehamilan yang tidak diinginkan, besar keluarga yang direncanakan, persetujuan pasangan, bahkan norma budaya lingkungan dan orangtua (Saifuddin, 2006).

Kontrasepsi hormonal jenis KB suntik di Indonesia semakin banyak digunakan karena kerjanya yang sangat 
efektif, pemakaiannya yang praktis, harganya relatif murah dan aman. Kontrasepsi suntik adalah cara untuk mencegah terjadinya kehamilan dengan memasukkan cairan atau obat berupa suntikkan hormonal ke dalam tubuh. Suntikkan ini bertujuan untuk mencegah ovulasi, mengentalkan lendir serviks sehingga menurunkan kemampuan penetrasi sperma, menjadikan selaput lendir Rahim tipis dan atrofi, menghambat transportasi gamet oleh tuba. Memiliki efektifitas yang tinggiya itu sebesar 0,3 kehamilan per 100 perempuan/tahun, asal penyuntikannya dilakukan secara teratur jadwal yang telah ditentukan (Saifuddin, 2010).

Laju pertumbuhan penduduk (growth rate) ditentukan oleh tingkat kelahiran dan kematian. Dengan perbaikan kesehatan ditingkat kematian menurun, sedangkan tingkat kelahiran masih tetap tinggi dengan akibat naiknya laju pertumbuhan penduduk (Winkjosastro, 2014).

Angka kelahiran di negara-negara berkembang pada umumnya tidaklah seberapa meninggi, walaupun tidak turun juga secara drastis. Jadi penyebab utama laju pertumbuhan penduduk pada tahap II berasal dari komponen kematian, namun pemecahan masalah harus diusahakan dari komponen kelahirannya itu berusaha menurunkan kelahiran bukan dengan meninggikan angka kematian (Winkjosastro, 2014).

Angka Kematian Ibu (AKI) sebagai salah satu indikator kesehatan ibu maternal, kematian merupakan akibat langsung dari kehamilan. Untuk mengurangi resiko kematian ibu bersalin, seorang ibu perlu melakukan pengaturan kehamilan yang sehat dengan ber-Keluarga Berencana (KB) (Depkes,2014).

Menurut WHO (World Health Organization) keluarga berencana adalah tindakan yang membantu individu dan pasangan suami istri untuk mendapatkan objektif-objektif tertentu, menghindari kelahiran yang tidak diinginkan, mendapatkan kelahiran yang memang diinginkan, mengatur interval diantara kehamilan, mengontrol waktu saat kelahiran dalam hubungan dengan suami istri, menentukan jumlah anak dalam keluarga (Hartanto, 2011).

Ada beberapa metode atau alat kontrasepsi yang bisa digunakan, bagi wanita lain antara pil KB, Suntik KB, susuk atau implant, Kondom, Alat Kontrasepsi Dalam Rahim (AKDR) dan Medis Operasi Wanita (MOW) biasa disebut tubektomi sedangkan bagi pria biasanya dengan cara pantang berkala, senggama terputus, kondom dam Medis Operasi Pria (MOP) atau vasektomi (Manuaba,2014).

Berdasarkan sekian banyak alat kontrasepsi yang beredar di masyarakat alat kontrasespsi yang paling popular di Indonesia adalah kontrasepsi suntik. Kontrasepsi suntik merupakan alat kontrasepsi yang berupa cairan yang berisikan hormone progesterone ataupun estrogen dan progesterone yang disuntikkan dalam tubuh wanita secara periodik (Depkes RI, 2015).

Menurut World Health Organization (WHO) penggunaan kontrasepsi telah meningkat di berbagai dunia. Terutama Asia dan Amerika Latin dan terendah di sub-sahara Afrika secara global. Penggunaan kontrasepsi modern telah meningkat tidak signifikan dari $54 \%$ pada tahun 2014 menjadi 57,4\% tahun 2015. Secara ragional, porposi pasangan usia subur 15-49 tahun melaporkan pengguna metode kontrasepsi modern telah meningkat minimal 6 tahun terakhir. Di Afrika dari 23,6\% menjadi $27.6 \%$, di Asia telah meningkat dari $60.9 \%$ menjadi
61.6\%. Sedangkan Amerika Latin dan Karibia naik sedikit dari $66.7 \%$ menjadi $67.0 \%$.

Diperkirakan 225 juta perempuan di negara-negara berkembang ingin menunda atau menghentikan kesuburan tetapi tidak menggunakan metode kontrasepsi apapun dengan alasan terbatas pilihan metode kontrasepsi dan pengalaman efek samping. Kebutuhan yang belum terpenuhi untuk kontrasepsi masih tinggi ketidakadilan di dorong oleh pertumbuhan populasi. Cakupan peserta keluarga berencana (KB) aktif di Indonesia pada tahun 2015 dengan jumlah pasangan usia subur (PUS) sebanyak 47.019.002 peserta KB Aktif sebanyak 35.202.908 meliputi IUD 3.896.081 (11\%) , MOW sebanyak 1.238 .749 (3.52\%) MOP 241.642 (0.69\%) Implan 3.680 .816 (10.46\%) kondom 1.110.341 (3.15\%) suntik sebanyak 16.734 .917 (47.54\%) dan pil 8.300.362 (29.58\%) (Depkes RI, 2014)

Berdasarkan hasil survei peserta KB aktif tahun 2015 menunjukan kontrasepsi suntik masih menja dipilihan utama pada pasangan usia subur (PUS) dengan persentase KB suntik 53.80\%, Pil 28.30\%, Implan 21.99\%, IUD $6.79 \%$, MOW 5.59\%, MOP 0.49\%, kondom 3.69\% . Berdasarkan hasil survey peserta KB aktif di Indonesia pada tahun 2015 dan cakupan peserta KB baru dan aktif di Indonesia pada tahun 2014 tidak jauh berbeda dengan data yang diperoleh dari data Depkes RI (BKKBN, 2015).

Saat ini penduduk Indonesia berjumlah kurang lebih 228 juta jiwa dengan pertumbuhan penduduk 1,64\% dan Total Fertility Rate (TFR) 2.6. Dari segi kuantitas jumlahpenduduk Indonesia cukup besar tetapi segi kualitas melalui indeks pembangunan manusia (IPM) kondisi sangat memprihatinkan karena dari 117 negara Indonesia di posisi 108 . Tingginya laju pertumbuhan tidak diiringi kualitas ini terus dilakukan upaya penanganan program keluarga berencana (KB) (Ambarwati, 2014)

Berdasarkan Profil Kesehatan Kalimantan Timur tahun (2015) cakupan peserta KB aktif per kabupaten/kota masih harus diperbaiki, Bontang 21\%, Samarinda 45\%, Kutai Timur 48\%, Kutai Barat 50\%, Kutai Kartanegara $60 \%$, Paser 66\%, Berau 66\%, Balikpapan 75\%, Penajam Paser Utara 88\%, Mahulu 92\%.

Berdasarkan data yang di peroleh dari BKKBN Provinsi Kalimantan Timur tahun (2015), Paser yang menggunakan IUD sebanyak 1.011, Pil 8.166, Kondom 536, Suntik 14.530, Implant 1.263. Kutai Barat IUD 7 , Pil 2.464, Kondom 36, Suntik 6.038, Implant 3.161. Kutai Kartanegara IUD 4.270, Pil 24.247, Kondom 1.151, Suntik 22.258, Implant 3.161. Kutai Timur IUD 1.265, Pil 3.873, Kondom 816, Suntik 10.779, Implant 1.146. Berau IUD 1.011, Pil 8.166, Kondom 536, Suntik 14.530, Implaant 1.263. Penajam Paser Utara IUD 1.775, Pil 8.684, Kondom 1.336, Suntik 8.988, Implant 1.161. Balikpapan IUD 12.585, Pil 19.294, Kondom 2.882, Suntik 30.380, Implant 4.716 Samarinda IUD 16.966, Pil 32.617, Kondom 1.668, Suntik 36.207 Implant 5.083 Bontang IUD 3.468, Pil 5.955, Kondom 1.798,Suntik 10.758 Implant 1.195

Berdasarkan Profil Kesehatan Balikpapan tahun (2015) jumlah peserta akseptor KB kota Balikpapan 85.370, jenis kontrasepsi yang di minati oleh akseptor KB suntik mencapai 36.189 (42.40\%), IUD 12.813 (15.00\%), Implant mencapai 5.498 (6.40\%), Pil mencapai 20.933 ( 24.50\%), MOP mencapai 267 (0.30\%) MOW mencapai 2.964 (3.50\%) Kondom mencapai 3.940 ( 4.60\%).

Berdasarkan data Puskesmas Baru Ulu Balikpapan pada bulan April 2017 jumlah PUS sebanyak 1.100 jiwa dan 
Ni Nyoman Widya Pradani. Hubungan Tingkat Pendidikan Ibu ...

yang menjadi peserta KB Aktif 488 orang. Kontrasepsi yang digunakan Pil 290 (59,42\%), Suntik 196 (40,16\%), Implant $4(0,80 \%)$, IUD $3(0,65 \%)$, MOW dan MOP tidakada $(0,00 \%)$.

Berdasarkan data Puskesmas Gunung Samarinda Balikpapan pada bulan Januari hingga April 2017, jumlah PUS sebanyak 1.290 jiwa dan pasangan usia subur (PUS) bukan peserta KB sebanyak 91 jiwa. Kontrasepsi yang digunakan adalah sebagai berikut IUD 10 (0.77\%), MOW 8 (0.62\%), MOP 5 (0.38\%), Kondom 135 (10.46\%), Implant 182 (14,10\%), Suntik 473 (37,0\%), Pil 386 (30,0\%).

Berdasarkan uraian di atas maka penulis tertarik untuk melakukan penelitian dengan judul "Hubungan Tingkat Pendidikan Ibu Dengan Pemilihan Alat Kontrasepsi KB Suntik di Puskesmas Gunung Samarinda tahun 2017"

Tujuan penelitian ini adalah untuk menganalisis dan menjelaskan hubungan pendidikan ibu dengan pemilihan alat kontrasepsi KB Suntik di wilayah kerja Puskesmas Gunung Samarinda Balikpapan.

\section{B. METODE PENELITIAN}

Penelitian ini merupakan penelitian kuantiftatif menggunakan metode survey, bersifat deskriptif analitik dengan menggunakan rancangan cross sectional. Analisa data meliputi univariat (distribusi frekuensi), bivariat (chi square). Populasi dalam penelitian ini adalah seluruh akseptor KB yang ada di wilayah kerja Puskesmas Gunung Samarinda Balikpapan yaitu berjumlah 1.199 jiwa. Sampel sebanyak 92 responden diambil secara accidental sampling.

\section{HASIL DAN PEMBAHASAN}

\section{Analisa Univarat}

\section{1) Pendidikan}

\section{Tabel 1}

Distribusi Frekuensi Responden Menurut Pendidikan Ibu di Wilayah Kerja Puskesmas Gunung Samarinda Kota Balikpapan Tahun 2017

\begin{tabular}{cccc}
\hline No & Pendidikan & $\begin{array}{c}\text { Jumlah } \\
\text { (n) }\end{array}$ & $\begin{array}{c}\text { Persentase } \\
\text { (\%) }\end{array}$ \\
\hline 1 & Tinggi & 10 & 10,9 \\
2 & Menengah & 36 & 39,1 \\
3 & Rendah & 46 & 50,0 \\
\hline & Total & $\mathbf{9 2}$ & $\mathbf{1 0 0 , 0}$ \\
\hline
\end{tabular}

2) Pemilihan alat kontrasepsi KB suntik

Tabel 2

Distribusi Frekuensi Responden Menurut Pemilihan Alat Kontrasepsi Puskesmas Gunung Samarinda Kota Balikpapan Tahun 2017

\begin{tabular}{cccc}
\hline No & $\begin{array}{c}\text { Pemilihan Alat } \\
\text { Kontrasepsi KB Suntik }\end{array}$ & $\begin{array}{c}\text { Jumlah } \\
\text { (n) }\end{array}$ & $\begin{array}{c}\text { Persentase } \\
(\mathbf{\%})\end{array}$ \\
\hline 1 & Memilih & 75 & 81,5 \\
2 & Tidak Memilih & 17 & 18,5 \\
\hline & Total & $\mathbf{9 2}$ & $\mathbf{1 0 0 , 0}$ \\
\hline
\end{tabular}

Berdasarkan tabel 2 diatas diketahui sebagian besar akseptor KB memilih KB suntik di Puskesmas
Gunung Samarinda Kota Balikpapan sebanyak 75 orang $(81,5 \%)$.

\section{Analisa Bivariat}

Tabel 3

Crosstab Pendidikan Ibu dengan Pemilihan Alat Kontrasepsi KB Suntik di Puskesmas Gunung Samarinda Kota Balikpapan Tahun 2017

\begin{tabular}{lcccccccc}
\hline \multirow{2}{*}{ Variabel } & \multicolumn{2}{c}{ Pemilihan Alat Kontrasepsi } & n & \% & $\begin{array}{c}\mathbf{p} \\
\text { value }\end{array}$ & $\begin{array}{c}\chi^{2} \\
\text { Hitung }\end{array}$ \\
\cline { 2 - 9 } & Memilih & \% & $\begin{array}{c}\text { Tidak } \\
\text { Memilih }\end{array}$ & \% & & & & \\
\hline Pendiidikan & 4 & 40,0 & 6 & 60,0 & 10 & 100 & & \\
\hline Tinggi & 30 & 83,3 & 6 & 16,7 & 36 & 100 & 0,001 & 13,291 \\
Menengah & 41 & 89,1 & 5 & 10,9 & 46 & 100 & & \\
Rendah & 41 &
\end{tabular}

Berdasarkan tabel 3 dapat dilihat bahwa dari 92 responden, didapatkan hasil dari 11 responden dengan kategori pendidikan tinggi, 4 orang $(40,0 \%)$ yang memilih KB Suntik, dan 6 orang $(60,0 \%)$ tidak memilih KB Suntik. Hasil dari 36responden dengan kategori pendidikan menengah, 30 orang $(83,3 \%)$ memilih KB Suntik, dan 6 orang (16,7\%) tidak memilih KB Suntik. Hasil dari 46 responden dengan kategori pendidikan rendah, 41 orang $(89,1 \%)$ memilih KB Suntik, dan 5 orang $(10,9 \%)$ tidak memilih KB Suntik.

Untuk mengetahui Hubungan antara Pendidikan ibu dengan pemilihan alat kontrasepsi KB Suntik dilakukan Uji Chi Square $\left(\chi^{2}\right)$ dengan batasan kemaknaan 0,05 dan $\mathrm{dk}=$ $(2-1)(3-1)=2$ di peroleh $\chi^{2}$ hitung 13.291sedangkan uji $\chi^{2}$ tabel 5.991. Jika dibandingkan, nilai $\chi^{2}$ hitung lebih besar dari $\chi^{2}$ tabel ( $\chi^{2}$ hitung 13.291> $\chi^{2}$ tabel 5.991).

Dengan demikian dapat disimpulkan ada hubungan yang signifikan antara tingkat pendidikan dengan pemilihan alat kontrasepsi KB Suntik.

\section{PEMBAHASAN}

Dari hasil penelitian tentang Hubungan Tingkat Pendidikan Ibu dengan Pemilihan Alat Kontrasepsi KB Suntik di Puskesmas Gunung Samarinda Kota Balikpapan Tahun 2017 ditemukan bahwa tingkat pendidikan rendah sebanyak 46 orang (50\%), pendidikan menengah 36 orang $(39,1 \%)$, dan pendidikan tinggi sebanyak 10 orang (10,9\%). Dari 92 responden sebanyak 75 orang $(81,5 \%)$ memilih KB suntik, 17 orang (18,5\%) tidak memilih.

Ibu yang berpendidikan rendah adalah ibu yang memilih sebesar 41 orang $(89,1 \%)$ dan tidak memilih 5 orang $(10,9 \%)$, sebanyak 30 orang $(83,3 \%)$ memilih, 6 orang $(16,7)$ tidak memilih yang berpendidikan menengah, dan sebanyak 4 orang $(40,0 \%)$ memilih, dan 6 orang $(60,0 \%)$ tidak memilih alat kontrasepsi KB suntik pada tingkat pendidikan tinggi. Hal ini terjadi karena faktor pendidikan. Hal ini dibenarkan oleh pernyataan Astuti (2010), Jika tingkat pendidikannya rendah maka dalam memberikan pelayanan terhadap pasangan usia subur (PUS) tidak akan tercapai, begitu juga dalam hal memahami pengarahan yang diberikan sehingga daya serap yang dimiliki juga rendah. Namun apabila sebaliknya jika mempunyai pendidikan yang bagus maka penyampaian suatu informasi dapat mudah diterima oleh penerima informasi maupun mudah dalam penyampaian terhadap pasangan usia subur terutama dalam pelayanan keluarga berencana oleh informan. 
Hal ini bias terjadi karena factor pendidikan, karena Semakin tinggi pendidikan seseorang, semakin mudah menerima Informasi, sehingga semakin banyak pula pengetahuan yang dimiliki. Sebaiknya pendidikan yang kurang akan menghambat perkembangan sikap seseorang terhadap nilai-nilai yang di perkenalkan (Notoadmojo, 2010).

Hal ini terjadi karena beberapa factor dimana pendidikan seseorang atau masyarakat dalam menerima informasi dan pengetahuan lebih mudah di serap dan di mengerti dan tidak menghambat perkembangan sikap seseorang terhadap nilai-nilai yang baru di perkenalkan (Siti Pariani, 2001).

Sitopu (2012) mengatakan bahwa pengetahuan akseptor KB berhubungan dengan penggunaan alat kontrasepsi. Semakin tinggi tingkat pendidikan seseorang semakin baik pengetahuan seseorang tentang alat kontrasepi dan semakin rasional dalam menggunakan alat kontrasepsi. Tingginya tingkat pendidikan seseorang juga akan mendukung mempercepat informasi KB pada pasangan usia subur.

Menurut Ali (2013) menyatakan bahwa pendidikan dan ketersedian alat kontrasepsi berhubungan dengan pemakaianalat KB pada PUS. Pendidikan berhubungan dengan penggunaan alat kontrasepsi pada PUS karena rendahnya pendidikan PUS menjadikan kontrasepsi kurang diminati, hal ini berdampak pada banyaknya anak yang dilahirkan dengan jarak persalinan yang dekat dan banyaknya PUS yang memilih KB suntik.

Pendidikan formal responden yang sebagian besar berpendidikan menengah dan rendah akan lebih sulit menerima informasi yang datang dari luar. Mereka bahkan cenderung akan mempertahankan informasi turun temurun tentang berbagai hal daripada mereka yang berpendidikan tinggi. Dari hasil penelitian diatas ada hubungan dengan teori yang adaya itu makin tinggi pendidikan seseorang makin mudah menyerap dan memahami apabila mendapat informasi mengenai alat kontrasepsi.

Berdasarkan data yang peneliti peroleh di lapangan, responden yang memilih alat kontrasepsi KB suntik adalah tingkat pendidikan rendah meliputi SD dan tidak sekolah, serta banyak memilih KB suntik 3 bulan. Oleh sebab itu kurangnya pengetahuan dan informasi ibu mengenai alat kontrasepsi menyebabkan wanita usia subur lebih memilih alat kontrasepsi suntik, untuk meningkatan pengetahuan ibu melalui pendidikan nonformal oleh petugas kesehatan tentang alat kontrasepsi sangat diperlukan untuk mengenalkan berbagai alat kontrasepsi KB agar pasangan usia subur tidak hanya menggunakan KB suntik 3 bulanatau 1 bulan saja tetapi pasangan usia subur bisa menggunakan alat kontrasepsi lain seperti IUD atau Implant yang keefektifannya lebih tinggi, tidak perlu mengingat kapan akan kembali suntik setiap 3 bulan.

Hal ini seperti dikemukakan oleh Notoatmodjo (2010), pendidikan adalah suatu kegiatan atau proses pembelajaran untuk mengembangkan atau meningkatkan kemampuan tertentu sehingga sasaran pendidikan itu dapat berdiri sendiri. Selain tingkat pendidikanya yang rendah, sumber informasi yang terbatas sehingga masih banyak pasangan usia subur yang belum memahami tentang alat kontrasepsi, macam-macam alat kontrasepsi, kekurangan dan kelebihan alat kontrasepsi tersebut.

\section{SIMPULAN DAN SARAN}

\section{SIMPULAN}

1. Sebagian besar tingkat pendidikan ibu di Puskesmas Gunung Samarinda adalah tingkat pendidikan rendah sebanyak 46 orang $(50,0 \%)$.

2. Sebagian besar responden di Puskesmas Gunung Samarinda Balikpapan, memilih alat kontrasepsi KB suntik 75 orang $(81,5 \%)$.

3. Hasil analisa statistik menunjukkan bahwa hubungan pendidikan ibu dengan pemilihan alat kontrasepsi KB suntik diperoleh hasil $\mathrm{P}_{\text {value }} 0,001<\alpha 0,05$ batas kemaknaan,atau nilai $\chi^{2}$ hitung 13,291 yang mana masih lebih besar dari $\chi^{2}$ tabel 5,991 yang berarti HO ditolak dan Ha diterima, artinya ada hubungan tingkat pendidikan ibu dengan pemilihan alat kontrasepsi KB suntik.

\section{SARAN}

1. Bagi Responden

Dapat digunakan sebagai pengetahuan dan menambah informasi bagi responden untuk meningkatkan pengetahuan dan informasi ibu tentang alat kontrasepsi, jenis-jenis kontrasepsi, keuntungan dan kerugian kontrasepsi.

2. Bagi Tempat Penelitian

Dapat digunakan sebagai bahan masukan bagi instansi kesehatan untuk memberikan informasi, penyuluhan mengenai alat kontrasepsi, dapat dengan memasang poster-poster $\mathrm{KB}$ di area Puskesmas Gunung Samarinda Balikpapan, serta dengan memberikan leaflet mengenai alat kontrasepsi.

3. Bagi Peneliti

Menambah pengalaman dan wawasan serta sebagai bahan untuk menerapkan ilmu didapatkan dari hasil penelitian yang telah dilakukan.

4. Bagi Peneliti Lain

Diharapkan penelitian ini dapat memberikan manfaat yang dapat dijadikan sebagai bahan untuk referensi tambahan bagi peneliti lainnya, sehingga peneliti lainnya mampu untuk melakukan penelitian yang lebih baik lagi.

5. Bagi AKBID Bakti Indonesia Balikpapan

Dapat dijadikan untuk bahan referensi atau untuk penelitian selanjutnya.

\section{UCAPAN TERIMA KASIH}

Tim penulis mengucapkan terima kasih kepada UM Mataram yang telah menyetujui untuk paper ini diterbitkan serta seluruh pihak yang telah membantu dalam penelitian ini yang tidak dapat kami sebutkan satu persatu.

\section{DAFTAR RUJUKAN}

[1] Abu Ahmadi. Psikologi Sosial. Edisi ke-6. Jakarta: PT. Rineka Cipta. 2010 
[2] Affandi, B. Buku Panduan Praktis Pelayanan Kontrasepsi. Edisi 3. Jakarta: PT. Bina Pustaka Sarwono Prawirohardjo. 2010

[3] Ali, H. Zaidin. Pengantar Pelayanan Kontrasepsi. Jakarta. 2013

[4] Ambarwati, Eny Retna. Asuhan Kebidanan, Yogyakarta: Nuha Medika. 2014

[5] Anwar, M., Baziad, A. Teknologi Kontrasepsi. YBC. Jakarta : YBC. 2011

[6] Arikunto, Suharsimi. Prosedur Penelitian Suatu Pendekatan Praktek. Jakarta : Rineka Cipta. 2008

[7] Astuti, E. Deskriptif Faktor yang Mempengaruhi Wanita Usia Subur (WUS) Tidak Menggunakan Alat Kontrasepsi. Akademi Kebidanan YLPP Purwakarta Vol 5 No. 2 BKKBN. Pelayanan Kontrasepsi Bidan. Jakarta. 2010

[8] Depkes RI. Pedoman Keluarga Berencana Direktorat Pembinaan Kesehatan Masyarakat. Jakarta. 2014

[9] Dinas Kesehatan Kota Balikpapan. 2012. KB Balikpapan (online) http://newsbalikpapan.com/kb-balikpapan-siapaturan.http://www.kaltimpost.co.id diakses 16 Mei 2014.

[10] Hartanto, Hanafi. Keluarga Berencana dan Kontrasepsi. Jakarta: Pustaka Sinar Harapan. 2011

[11] Hindayani, S. Buku Ajar Pelayanan Keluarga Berencana, Yogyakarta: Pustaka Rihama. 2010

[12] Manuaba, IBG. Ilmu Kebidanan Penyakit Kandungan dan KB. Jakarta: EGC. 2010

[13] Manuaba, I Gede. Ilmu Kebidanan. Penyakit Kandungan dan Keluarga Berencana Untuk Pendidikan Bidan. Jakart: EGC. 2014

[14] Notoadmojo, Soekidjo. Metodologi Penelitan Kesehatan. Jakarta : Rineka Cipta. 2010

[15] _. Pengetahuan dan Sikap. Jakarta: Rineka Cipta. 2005

[16] Metodologi Penelitian Kesehatan. Jakarta: Rineka Cipta. 2012

[17] Saifuddin,AB. Buku Panduan Praktis Pelayanan Kontrasepsi. Jakarta : YBP. 2010

[18] Saryono. Metodelogi Penelitian Kebidanan. Nuha Medika. Jakarta. 2010

[19] Sitopu, Selli Dosriani. Pelayanan Keluarga Berencana. Jakarta. 2012.

[20] Syafrudin. Penyuluhan Kesehtan Pada Keluarga. Jakarta: Trans Info Media. 2011

[21] Wiknjosastro, Hanifa. Kontrasepsi, Ilmu Kebidanan. Jakarta: Yayasan Bina Pustaka Sarwono Prawirohardjo. 2014.

\section{PROFIL PENULIS UTAMA}

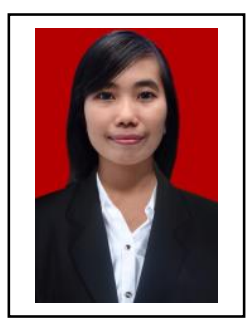

Ni Nyoman Widya Pradani,S.ST.,M.Kes Lahir di Samarinda, 01 Mei 1989. Setelah lulus SMA melanjutkan kuliah DIII Kebidanan di Poltekkes Kemenkes Kalimantan Timur. Pada Tahun 2010 lulus dan bekerja sebagai bidan pelaksana di Puskesmas Kejawi Kutai Kartanegara. Penulis melanjutkan kuliah DIV Kebidanan (Bidan Pendidik) di Poltekkes Kemenkes Kaltim. Pada tahun 2012 penulis bergabung di Akademi Kebidanan Bakti Indonesia Balikpapan dan melanjutkan kuliah Pascasarjana Program Studi Ilmu Kesehatan Masyarakat Peminatan Kesehatan Reproduksi di Universitas Respati Indonesia pada tahun 2014 dan lulus di tahun 2016. Setelah menikah, penulis berdomisili dan bekerja di Kota Balikpapan. Saat ini penulis sebagai dosen tetap di Akademi Kebidanan Bakti Indonesia Balikpapan. 